\title{
STRATEGIES FOR SUCCESSFUL ENTRY OF BANDUNG CREATIVE SMES IN FOREIGN MARKET Case Study: Little Bandung in Korea
}

\author{
Novika Candra Astuti \\ Faculty of Business and Management, Widyatama University, Bandung \\ email: novika.candra@widyatama.ac.id
}

\begin{abstract}
ABSTRAK
Little Bandung adalah sebuah program pemerintah kota Bandung untuk membantu UKM di bidang industri kreatif memasuki pasar luar negeri. Penelitian ini bertujuan untuk mengetahui hambatan, motivasi, harapan dan strategi dalam mempersiapkan UKM Bandung masuk pasar internasional. Penelitian ini menggunakan metode kualitatif dan kuantitatif untuk mengumpulkan data dengan melakukan Focus Group Discussion (FGD) dengan 15 responden (owner / manager) dari UKM di industri kreatif yang terdaftar dalam buku produk kreatif Bandung dan menyebarkan kuesioner untuk mendapatkan pemahaman yang lebih mendalam. Hasil penelitian menunjukkan bahwa lebih dari 90\% responden memiliki pengalaman berbisnis di pasar luar negeri seperti di Singapura dan Malaysia. Alasan utama memasuki pasar luar negeri adalah memenuhi pesanan pelanggan dan mengembangkan bisnis. Kekhawatiran utama yang dihadapi UKM dalam ekspor adalah masalah undang-undang dan peraturan dan persepsi tidak adanya market di luar negeri. Melalui pemanfaatan teknologi seperti website diusulkan sebagai platform yang akan menghubungkan situs dari masing-masing UKM serta perlunya pelaksanaan riset pasar untuk membantu UKM menganalisa pasar Korea. Selain itu, penelitian ini mengemukakan bahwa konsep dan manajemen Little Bandung di Korea harus dirancang lebih rinci untuk mempersiapkannya dengan baik sebelum UKM melakukan penetrasi ke negara tersebut.
\end{abstract}

Kata kunci: Bandung kecil, UKM, ekspor, industri kreatif

\begin{abstract}
Little Bandung is a concept to help Bandung creative SMEs to enter foreign market. This study aims to understand obstacles, motivation, expectation and strategies in preparing Bandung SMEs in international environment. This research used qualitative and quantitative method to collect data by conducting focus group discussion toward 15 respondents (owner/manager) from SMEs in creative industries listed in the Book of Bandung creative products as well as spreading questionnaires to obtain deeper understanding. The results show that more than 90\% respondents have previous experience in foreign market such as in Singapore and Malaysia. The major reasons to enter foreign market are to fill customers' orders and develop business. The major concerns faced by SMEs in export are laws and regulation and perception of no market abroad. This study suggests that Bandung government should create a website as a platform that connect with each of SMEs' website and conduct market research to analyze Korean market. In addition, this study suggests that the concept and management of Little Bandung in Korea should be designed more detailed to prepare it well before SMEs penetrating abroad.
\end{abstract}

Keywords: little bandung, SMEs, export, creative industries

\section{INTRODUCTION}

Globalization is a continuous transform that displays opportunities, risks and challenges. The best challenge we confront today is to guarantee that globalization turns into a constructive power in the term of making worldwide business environment and business connections for the world's people (Czinkota and Ronkainen 2013). Nowadays, globalization is a key driver that brings an effect on nearly all businesses including SMEs. The business environment of SMEs has changed drastically in the era of globalization. This era has affected SMEs both positive and negative. It gives new chances for extension and growth by delivering preference in competitive markets. Nevertheless, the globalization is increasing tough competition among foreign enterprises and is resulting in aggressive difficulties and risks. SMEs generally often frequently experience the absence of workforce aptitudes and limitation of advanced administrative and difficulties in embracing new innovations; restricted access to finance; and lack of ability to meet the standardization, certifications and quality controls in international requirements. Therefore, 
SMEs need assistance in improving their productivity to be successful in international and global value chains.

Indonesia recognizes that creative industries are vital for economic growth and trade development in developing countries. Bandung is a model of city that develops the potential of creative economy, creates jobs, improves the quality of life and raises the brand of Bandung, West Java and Indonesia to the world (Kemenpar 2014). The growth of SMEs in Bandung statistically becomes one of the highest rates in Indonesia at $7.8 \%$, while Indonesia only grows $4.7 \%$. The percentage of SMEs is approaching $60 \%$ and fashion industry as a subsector of creative industries accounts for the highest rate of economic growth in Bandung.

Bandung is ready to face the era of the ASEAN Economic Community (AEC) by trying to make new innovations to maximize the marketing of Bandung creative products. One form of readiness is the promotion of local products made by young creativepreneurs from Bandung, such as Little Bandung. Little Bandung is one concept of marketing strategies for Bandung SMEs in order to go international. Little Bandung is also expected to increase brand image of Bandung. It provides three concepts; firstly, "Little Bandung Space" aims to open stores or boutiques in overseas; secondly, "Little Bandung Wall" is designed by hiring restaurants' walls that exist abroad with put Bandung creative products on the walls, and finally "Little Bandung Mobile" is exhibition that shows products from one city to other cities internationally.

Little Bandung is created to solve Bandung SMEs problems. Mayor of Bandung states that there are still many obstacles in improving the productivity of local products. There are five obstacles that hinder so the production is less than optimal, the constraints of technology, materials that are still supplied from outside the city of Bandung, human resources, capital, and marketing (indonesiaberinovasi.com). Mayor of Bandung has successfully created an area that introduced Little Bandung in Paris. He also has made a memorandum of understanding (MOU) with some ASEAN countries, such as Malaysia and Thailand, to be able to launch Bandung creative products.

The cooperation between the government of Bandung and several countries has been made to promote SME Bandung creative products in international market, but so far there is lack of study the needs and constraints of their preparations entering overseas markets. SMEs have less information regarding Little Bandung concept and management process. Therefore, a study is needed to fill the gap to help Bandung SMEs ready to enter unfamiliar markets that are different from domestic area. This study aims to investigate a useful strategy for preparing Bandung creative SMEs entering foreign market. The study also examines motivations and barriers of SMEs in internationalization process. This study is focused on exporting; a category of internationalization activities that most typically used by SMEs to sell their product to foreign customers.

This study gives significant contribution for extending the literature of SMEs internationalization in emerging countries, presenting insight for SMEs about the impetus and the obstacles going global so that can encourage SMEs who are reluctant to widespread their market, and providing suggestion for Bandung local government in preparing their program running well. This research examines barriers that hinder Bandung SMEs from going global and factors that encourage them to enter foreign market as well as expectation in preparing Little Bandung program. This research also is to find key strategies to be successful in foreign market.

Bandung government and School of Business and Management, Bandung Institute of Technology have produced a book of Bandung's Top Creative Products that represent superior products of SMEs Bandung.

Exporting is the most popular, fastest, and easiest for many smaller companies to expand the international market. Exports require fewer resources, offer greater flexibility of managerial actions, and involve lower business risk. Segal, Borgia and Schoenfeld (2005) states that motivations are critical dimensions to see readiness of firms to export. Motivation of export is defined as driving factors that influence companies to decide initiating and developing export activities (Leonidou et al., 2007). By operating abroad the firm may gain many advantages from international competition such as providing an opportunity to become less dependent on the domestic market, lowering production costs while producing more efficiently, becoming a stronger competitor at home (Lages and Montgomery 2004). According to Katsikeas (1996), there are two sources of research on motivation exports. The first source said that the motivation of exports divided into external and internal factors (Brooks and Rosson, 1982; Cavusgil, 1980; Kaynak 
and Stevenson, 1982; Miesenbock, 1988). External motivation factors include unwanted orders, the profit potential, large market size, and nearby foreign markets, and foreign distributor offer. Several internal factors include diversification, increased capacity utilization, the rise of growth business rate, and smoothing out of business cycles. Holmlund, Kock and Vanyushyn (2007) found that there are three most influencing factors in exporting namely management's interest, limited domestic market, and inquiries from buyers.

In internationalization process, the barriers faced by firms tend to differ in each stage (Morgan 1997). According to Morgan (1997), the literature related to research on traditional export restrictions tend to emphasize two forms of export barriers, namely: firstly, the problems that prevent the company from engaging in export activities and secondly, the problem experienced by companies that have started export operations. Morgan and Katsikeas (1998) classified three groups of export barriers: strategic barriers, operational barriers, and informational barriers. Export barriers are categorized also into five broad areas: financial, managerial, market-based (including both domestic and international markets), industry specific and firm specific (Shaw and Darroch 2004). According to Leonidou (2004), firms are struggle with getting information relate to identifying, selecting, and contacting international markets.

In early stage, firms tend to have difficulties in identifying opportunities in foreign markets (Bilkey and Tesar, 1977). Tesfom and Lutz (2006) claimed that absence of information in foreign market is the most severe issue of firms in developing countries. Numerous SMEs in developing countries faced some export barriers including lack of timely and adequate working capital that threaten production operation (Tesfom and Lutz 2006) and inability to make selffinance (Bilkey, 1978; Keng and Jiuan, 1989). Marketing function are recognized as problems by scholars such as achieving international quality standardization (Pinho and Martins, 2010), product adaptation (Kedia and Chhokar, 1986), transportation and distribution difficulties (Barker and Kaynak 1992), networking (Tesfom and Lutz, 2006), pricing (Da Rocha, et al., 2008), logistic and after sales service (Morgan and Katsikeas, 1997) and promotion program (Leonidou, 2004).

Previous studies argued that export barriers are affected to external environment. Tesfom and Lutz
(2006) stated that the external export barriers including distinctive foreign consumer preferences, unfamiliar business protocols and practice, the imposition of tariff barriers and regulatory import controls by foreign governments, fierce competition, and exchange rate risk. Other scholars mentioned that external issues related to export such as procedures and administration (Barker and Kaynak, 1992), communication dilemma and cultural disparity (Pinho and Martins 2010), political uncertainty in host country (Kaynak, Ghuari and OlofssonBredenlow, 1987), tough competition (Gripsrud 1990), lack of government support (Albaum, 1983), and differences of customer habit and attitudes (Shaw and Darroch, 2004).

Little Bandung as a government program to assist Bandung SMEs introducing their products abroad. Government support program as an "external agent change" give stimulus for domestic firms to be success in operating international business activities(Czinkota and Ronkainen, 2007). Government agencies assist a variety of initiatives related to export activities to overcome mental block and develop positive perception of owners/managers of SMEs (Shamsuddoha et al., 2009). (Singer and Czinkota, 1994) stated export assistance program can help managers improving, accelerating, and exchanging foreign market knowledge and increase their commitment in international market. (Gençtürk and Kotabe, 2001) argued that the usage of export assistance programmes influence both export efficiency and competitive position of the firm. In Indonesia, the government have a role in encouraging SMEs going abroad by initiating many programs and incentives such as training, cost for international exhibition, marketing channel, finance, and e-commerce facilities.

\section{RESEARCH METHOD}

This research employed a focus group discussion and used a questionnaire to collect data. This study was conducted in June 2015 collaborating with School of Business and Management, Bandung Institute of Technology to help Bandung government. The purposive sampling was applied in this sampling strategy to find out Bandung creative SMEs who have potential to export. Then, the researcher filtered the firms listed in Top 20 creative products and sent an email to invite them to engage in the FGD, however only fifteen SMEs agreed to participate. The respondents in this study are owner/ 
manager of SMEs who play a key role as a decision maker in firm's strategy.

\section{Focus Group Discussion (FGD)}

FGD is a qualitative method that provide an opportunity to a person of voice, encourage dialogue in a group and listen individual concerns (Saumure 2001). The average time to discuss is about 90 to 120 minutes with six to 15 participants where the researcher learn about the perceptions, feelings, attitudes, values and ideas of the respondents in an interest field (Kahan 2001). In this study, focus groups were used to explore the perceptions and the views of entrepreneurs toward Little Bandung in Korea. The discussion guide is provided to help the moderator to ask and probe questions. This FGD aims to formulate a plan or program to prepare Little Bandung especially in Korea and to get information regarding readiness of creativepreneurs. In the first stage, the moderator explained about Little Bandung program, the schema, related-people with Little Bandung. The research questions in the FGD discussed issues related to exports such as if you do export, what experiences do you have in entering foreign market?, what do you think to prepare your company selling product abroad especially for Little Bandung? What do you know about market in South Korea?, and suggestion for Little Bandung. All discussions groups were recorded, transcribed and then were analysed.

\section{Questionnaires}

To identify demographic profile of SMEs and to gain more detailed information from each company, the researcher continued with spreading the questionnaire. However, only 10 respondents were willing to fill out the questionnaire. The questionnaires covered a number of questions including demographic issues (organizational size, the number of employees, type of industry, export experience), company's strategic goals, reasons to engage in exporting, barriers hindering SMEs going global, and readiness for Little Bandung.

\section{RESULTS AND DATA ANALYSIS Result 1}

From the discussion in FGD, the researcher analysed some problems that appear and collected some suggestions proposed by respondents. The respondents presented some issues regarding Little
Bandung preparation such as store location, clients/ buyers, less experience doing export, lack of finance, shipping cost, time delivery, compensation for damages and loss, export documents, ISO, safety, bureaucracy, regulation, product selection in store, and people management.

In addition, the respondents proposed some solutions to prepare entering Korean market; they agreed to have consignment in the first three months but after that they want a normal purchase system. They suggested Bandung government to formulate the concept of Little Bandung clearly and make a negotiation, the program can be run and managed by private company, provide market research before launching Little Bandung in Korea, provide a market analyst, serve quality control management, warehousing, and form a cooperative (Koperasi), and establish a website as a platform will connect to each website of SME including the address of SMEs, the advantage of products, the type of their products (fabrication, handmade, and mixed), capacity of production.

\section{Result 2}

Based on data collection through questionnaire toward Bandung SMEs in creative industries, only ten respondents were participating in this research. Table 1 shows that $50 \%$ of respondents running business less than 3 years, 30\% have owned business between 3 and 7 years. Almost $60 \%$ respondents have less than 3 employees and $40 \%$ respondents have between 3 and 5 employees. Eighty percents of respondents from fashion industry such as clothing, shoes, and hijab (muslim veil). Although most of them are categorized as small business criteria, $90 \%$ of SMEs have experienced entering foreign market, for example Singapore (50\%) and Malaysia (40\%).

There is no surprise that SMEs choose Singapore and Malaysia as country to focus. These countries are assessed and chosen by the exporting SMEs as their international market due to its near location, easy access, good market base, and similar culture and language abilities as Indonesian market. They were not only exporting their products in ASEAN market but also doing export to Europe (Spain, Italy), even in Canada. From table 1 it can be seen that the most often method used to sell products by SMEs is through social media (80\%). 
Table 1. Profile of respondents

\begin{tabular}{|c|c|c|}
\hline Variable & Frequency & Percentage \\
\hline \multicolumn{3}{|l|}{ The length of business } \\
\hline Less than 3 years & 5 & $50 \%$ \\
\hline $3-7$ years & 3 & $30 \%$ \\
\hline $8-11$ years & 1 & $10 \%$ \\
\hline $\begin{array}{l}\text { More than } 11 \text { years } \\
\text { The number of emplo }\end{array}$ & 1 & $10 \%$ \\
\hline Less than 3 & 6 & $60 \%$ \\
\hline $\begin{array}{l}\text { 3-5 people } \\
\text { Industry's sector }\end{array}$ & 4 & $40 \%$ \\
\hline Fashion clothing & 4 & $40 \%$ \\
\hline Fashion shoes & 3 & $30 \%$ \\
\hline Hijab/scarf & 1 & $10 \%$ \\
\hline $\begin{array}{l}\text { Souvenir } \\
\text { Engaged in Export }\end{array}$ & 2 & $20 \%$ \\
\hline Exporter & 9 & $90 \%$ \\
\hline $\begin{array}{l}\text { Non-Exporter } \\
\text { Destination's export }\end{array}$ & 1 & $10 \%$ \\
\hline Malaysia & 4 & $40 \%$ \\
\hline Singapore & 5 & $50 \%$ \\
\hline Thailand & 1 & $10 \%$ \\
\hline Spain & 1 & $10 \%$ \\
\hline England & 2 & $20 \%$ \\
\hline Japan & 1 & $10 \%$ \\
\hline Italy & 1 & $10 \%$ \\
\hline $\begin{array}{l}\text { Canada } \\
\text { SMEs' method of sell }\end{array}$ & 1 & $10 \%$ \\
\hline Word of mouth & 2 & $20 \%$ \\
\hline Social Media & 8 & $80 \%$ \\
\hline Networking & 2 & $20 \%$ \\
\hline
\end{tabular}

The respondents were asked to state their goals over the next three years; the results are shown in figure 1. It is evident from the results that the main focus of over $90 \%$ of SMEs was growth in sales and market share, $70 \%$ of SMEs wanted to develop new products and services and 50\% of SMEs wanted to improve quality of work life for employees.

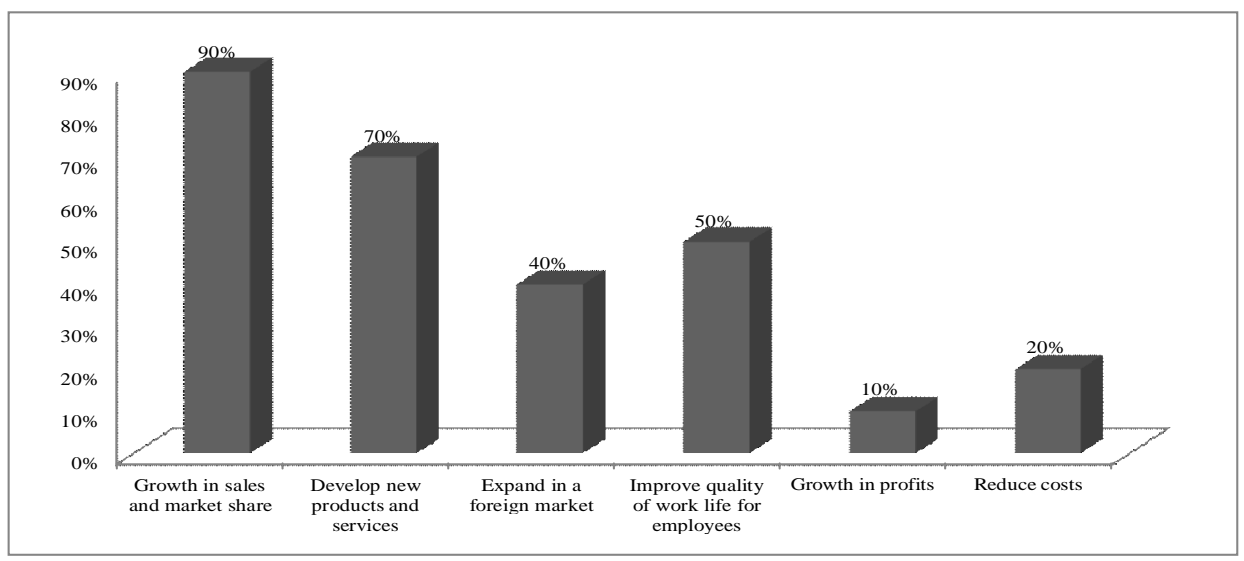

Figure 1 Company's strategic goals 


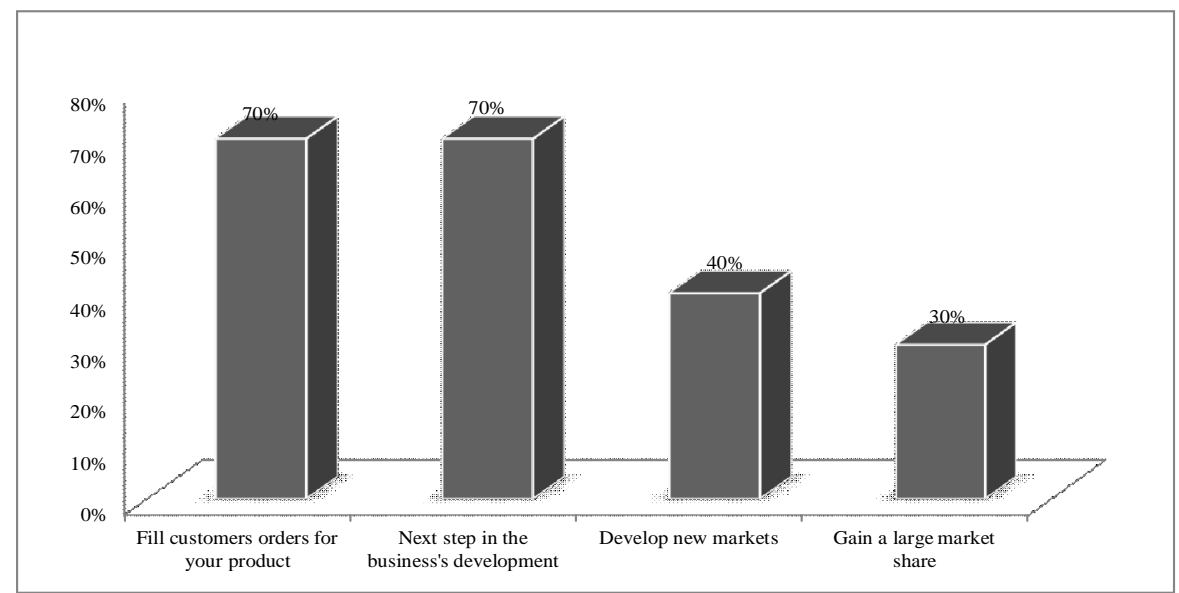

Figure 2 Reasons to engage in exporting

Some of these reasons SMEs pursuing an export strategy can be seen in Figure 2 where to fill customers' orders for products $(70 \%)$, have next step in the business's development, develop new markets (40\%) and gain a large market share (30\%) were found to be major reasons for entering foreign markets among the survey respondents.

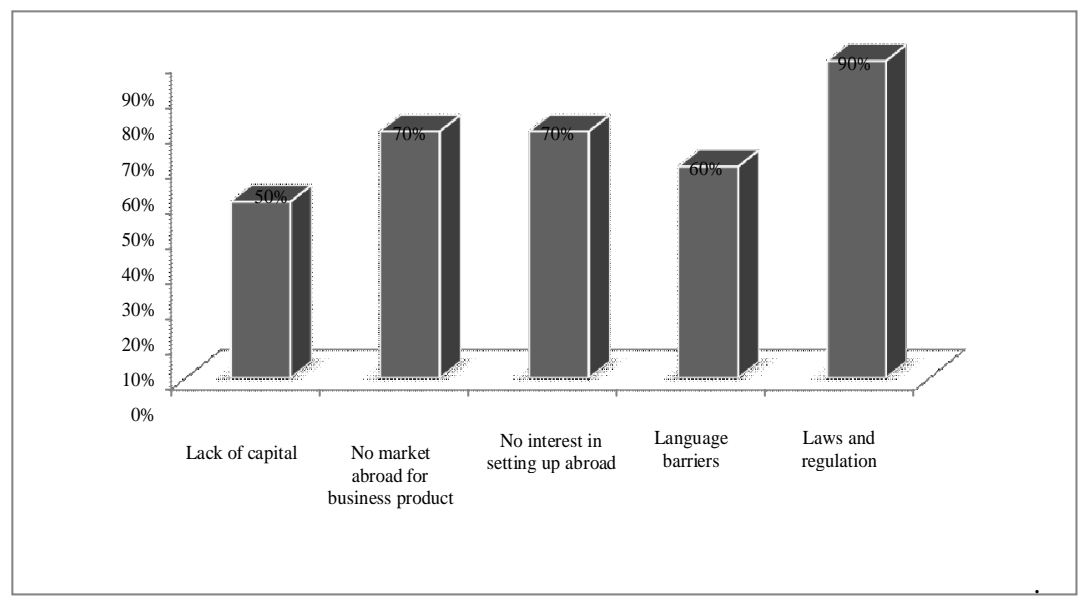

Figure 3 Barriers hindering SMEs going global

There is a need to investigate why many SMEs did not export or why they stopped exporting. By examining the barriers that hinder Bandung SMEs from going global it may understand what action needs to be taken to make international markets more accessible to SMEs. The findings reveal that SMEs agreed that laws and regulation (90\%) was a major barrier to them while perception of no market abroad for business products (70\%) and no interest in setting up abroad (70\%) also become problems for them. Language barriers $(60 \%)$ and lack of capital (50\%) were also cited by SMEs as obstacles when going foreign market.

\section{CONCLUSION}

Operating business in international market is not an easy task for small business company. To achieve goals, hinder failure and obtain desired profit, they should look for excellent strategy and plan it well. Exporting is mostly used by SMEs to enter foreign market due to its advantages that need less capital, provide larger flexible management, and contain minor business uncertainty. This study supports previous research that SMEs do export are motivated by to meet customer demand, to develop business, to enter new markets, and to acquire an enormous large market share. Bandung SMEs in creative industries have ambitions in the next three years to improve sales and market share, evolve new products and services, boost worker quality life, and penetrate in an overseas market. However, they face some problems namely laws and regulation, difficulty to find customers, no passion entering market abroad, and language barriers. Bandung government should be able to overcome the constraints currently faced. This research have 
examined some program to solve the dilemma managing Little Bandung in Korea such as firstly, conducting market research to investigate customer behaviour and lifestyle, secondly designing a website that is integrated with each SMES' website, thirdly establishing a place that has function like warehouse and quality control. Through this study, Bandung government should concern with bureaucracy issue and language barrier that government can facilitate though training to help Bandung creativepreneurs understand Korean market and prepare serving Korean customers well.

\section{REFERENCES}

Albaum, G. . 1983. Effectiveness of government export assistance for US. International Marketing Review 1 (1): 68-75.

Barker, A. T. and E. Kaynak. 1992. An empirical investigation of the differences between initiating and continuing exporters. European Journal of Marketing 26 (3): 27-36.

Bilkey, W. J. 1978. An attempted integration of the literature on the export behavior of firms. Journal of International Business Studies 9 (1): 33-46.

Bilkey, W. J. and G. Tesar. 1977. The export behaviour of smaller Wisconsin manufacturing firms. Journal of International Business Studies Spring/Summer: 93-98.

Czinkota, M.R. and I.A. Ronkainen. 2007. International Marketing. Thomson: Mason, $\mathrm{OH}$.

Czinkota, Michael R. and Ilkka A. Ronkainen. 2013. International Marketing Mason, $\mathrm{OH}$ : SouthWestern Cengage Learning.

Da Rocha, A., Y. A. Freitas and J. F. D. Dilva. 2008. Do perceived export barriers change over time? A longitudinal study of Brazilian exporters of manufactured goods. Latin American Business Review 9 (1): 102-128.

Gençtürk, Esra F. and Masaaki Kotabe. 2001. The Effect of Export Assistance Program Usage on Export Performance A Contingency Explanation. Journal of International Marketing 9 (2): 2001.

Gripsrud, G. . 1990. The determinants of export decision and attitude to a distant market: Norwegian fishery export to Japan. Journal of International Business Studies 21 (3): 469485.

Holmlund, Maria, Sören Kock and Vladimir Vanyushyn. 2007. Small and Medium- sized Enterprises' Internationalization and the Infl uence of Importing on Exporting. International Small Business Journal 25 (5): 459-475.

Kahan, J.P. . 2001. Focus groups as a tool for policy analysis. Analyses of Social Issue and Public Policy 1 (1): 129-146.

Kaynak, E., P. N. Ghuari and T. OlofssonBredenlow. 1987. Export behavior of small Swedish firms. Journal of Small Business Management 25 (2): 26-32.

Kedia, B. L. and J. Chhokar. 1986. Factors inhibiting export performance of firms: An empirical investigation. Management International Review 26 (4): 33-43.

Kemenpar. 2014. Siaran Pers Menparekraf Resmikan Simpul Space Untuk Komunitas Kreatif Bandung. http://www.kemenpar. go.id/ asp/detil.asp?c=16\&id=2743.

Keng, K. A. and T. S. Jiuan. 1989. Differences between small and medium sized exporting and non-exporting firms: Nature and nurture. International Marketing Review 6 (4): 27-40.

Lages, Luis Filipe and David B. Montgomery. 2004. Export performance as an antecedent of export commitment and marketing strategy adaptation. European Journal of Marketing 38 (9/10): 1186-1214. doi: 10.1108/03090560410548933.

Leonidou, Leonidas C. 2004. An analysis of the barriers hindering small business export development. Journal of Small Business Management 42 (3): 279-302.

Leonidou, Leonidas C., Constantine S. Katsikeas, Dayananda Palihawadana and Stavroula Spyropoulou. 2007. An analytical review of the factors stimulating smaller firms to export: implications for policy-makers. International Marketing Review 24 (6): 735-770.

Morgan, R. E. and C. S. Katsikeas. 1997. Obstacles to export initiation and expansion. International Journal of Management Science 25 (6): 677690.

Morgan, Robert E. 1997. Export stimuli and export barriers: evidence from empirical research studies. European Business Review 97 (2): 68-79.

Morgan, Robert E. and Constantine S. Katsikeas. 1998. Exporting Problems of Industrial Manufacturers. Industrial Marketing Management 27 (2): 161-176.

Pinho, José Carlos and Lurdes Martins. 2010. Exporting barriers: Insights from Portuguese small- and medium-sized exporters and nonexporters. Journal of International Entrepreneurship 8 (3): 254-272. doi: 10.1007/ s10843-010-0046- x. 
Saumure, K. 2001. Focus groups: an overview. University of Alberta: Alberta.

Segal, G., D. Borgia and J. Schoenfeld. 2005. The motivation to become an entrepreneur. International Journal of Entrepreneurial Behavior and Research 11 (1): 42-57.

Shamsuddoha, A. K., Nelson Oly Ndubisi, M. Yunus Ali and Nelson Oly Ndubisi. 2009. Impact of government export assistance on internationalization of SMEs from developing nations. Journal of Enterprise Information Management 22 (4): 408-422. doi: 10.1108/ 17410390910975022.
Shaw, Vivienne and Jenny Darroch. 2004. Barriers to Internationalisation: A Study of Entrepreneurial New Ventures in New Zealand. Journal of International Entrepreneurship 2 (4): 327-343.

Singer, Thomas Owen and Michael R. Czinkota. 1994. Factors Associated with Effective Use of Export Assistance. Journal of International Marketing 2 (1): 1994.

Tesfom, G. and C. Lutz. 2006. A classification of export marketing problems of small and medium sized manufacturing firms in developing countries. International Journal of Emerging Markets 1 (3): 262-381. 